\title{
A Defense of the War Powers Resolution
}

During the Vietnam era, public concern over the legitimacy of U.S. military involvement in Indochina heightened interest in the constitutional division of the war powers. Congressional efforts to ensure legislative control over future decisions to commit forces abroad culminated in 1973 in the passage, over President Nixon's veto, of the War Powers Resolution. ${ }^{1}$ The war powers issue remains unsettled, however, as the Resolution has been attacked as an unconstitutional and ill-advised attempt to legislate a new allocation of the war powers. The controversy over the Resolution's constitutionality has intensified during the past year as a result of the Supreme Court's decision in Immigration $\&$ Naturalization Service $v$. Chadh $a,{ }^{2}$ which apparently invalidated the legislative veto, and of Congress' efforts to reassert its institutional authority in response to President Reagan's use of American troops in Lebanon and Grenada.

This Note examines the constitutional sources of the President's independent power to make war. It argues that whatever authority the President has to initiate American involvement in hostilities abroad need not be based, as many commentators assume, on his role as Commander-inChief, ${ }^{3}$ which is not subject to restrictions by Congress. Rather, that authority derives from the general grant of "executive power" to the President. As a result, although the Executive may use force abroad during emergencies without prior congressional authorization, Congress may channel this power with concurrent resolutions or statutes. The Note concludes that the War Powers Resolution is constitutional and that it provides a desirable restriction on the President's capacity to make war when Congress is silent.

\section{The War Powers Resolution of 1973}

The War Powers Resolution governs the decision to introduce American armed forces into hostilities or into situations in which involvement in hostilities appears "imminent."4 Nonetheless, the Resolution has been subjected to conflicting interpretations, each arguably unconstitutional,

1. Pub. L. No. $93-148,87$ Stat. 555 (codified at 50 U.S.C. $\S \S 1541-48$ (1976)).

2. 103 S. C.t. 2764 (1983).

3. E.g., Berger, War-Making by the President, 121 U. PA. L. Rev. 29, 36-39, 80-81 (1972); Wormuth, The Nixon Theory of the War Power: A Critique, 60 CALIF. L. Rev. 623, 629-52 (1972). See generally L. TRIBe, American Constitutional Law § 4-6, at 173 (1978) ("it has become the practice to refer to the Commander in Chief Clause for whatever inherent martial authority the Executive may possess").

4. 50 U.S.C. $\S 1543(a)$ (1976). 
and has failed to produce a new consensus on the division of war powers between the President and Congress.

\section{A. Provisions That Allocate the Authority to Make War}

The scheme of the Resolution appears relatively straightforward. Section 2(c), which is part of the "Purpose and Policy" section, states that in the absence of a declaration of war or specific statutory authorization, "[t]he constitutional powers of the President as Commander-in-Chief" to introduce armed forces into hostilities or into situations where hostilities are imminent "are exercised only pursuant to . . . a national emergency created by attack upon the United States, its territories or possessions, or its armed forces." Section 4(a)(1) requires the President to submit a report to Congress within forty-eight hours of U.S. military involvement in hostilities. ${ }^{6}$ Section 5, entitled "Congressional Action," requires the President to terminate U.S. involvement not more than sixty days (ninety days if required by "unavoidable military necessity") after such a report is submitted or required to be submitted, unless Congress "has declared war or has enacted a specific authorization for [the involvement]." The section also allows Congress to remove U.S. forces engaged in hostilities abroad by concurrent resolution if there has been neither a declaration of war nor specific statutory authorization. ${ }^{8}$

Only once has Congress enacted statutory authorization pursuant to section 5. In the Multinational Force in Lebanon Resolution of October 12,1983 , Congress stated that U.S. forces in Lebanon "are now in hostilities requiring authorization of their continued presence under the War Powers Resolution." It then authorized the participation of U.S. forces in the Multinational Force in Lebanon for the following eighteen months. ${ }^{10}$

5. 50 U.S.C. $\S 1541$ (c) (1976). Article II, § 2, cl. 1 of the Constitution states: "The President shall be Commander in Chief of the Army and Navy of the United States, and of the Militia of the several States, when called into the actual Service of the United States . . .."

6. Section 4(a) provides: "In the absence of a declaration of war, in any case in which United States Armed Forces are introduced-(1) into hostilities or into situations where imminent involvement in hostilities is clearly indicated by the circumstances . . . the President shall submit within 48 hours to the Speaker of the House of Representatives and to the President pro tempore of the Senate a report, in writing . . . " 50 U.S.C. $\S 1543$ (a) (1976).

7. 50 U.S.C. $\S 1544$ (b) (1976).

8. 50 U.S.C. $\S 1544$ (c) (1976). Other sections of the Resolution treat presidential consultation with Congress, $\S 1542$, additional reporting by the President, $\S 1543(\mathrm{~b})$-(c), referral of reports to congressional committees, $\S 1544$ (a), the granting of priority to bills or resolutions under the Resolution, $\S \S 1545-1546$, interpretation of the Resolution, $\S 1547$, and separability of the Resolution's provisions, $\S 1548$.

9. Multinational Force in Lebanon Resolution, Pub. L. No. 98-119, § 2(a)(5), 97 Stat. 805, 805 (1983).

10. Id. $\S \S 3,6,97$ Stat. at 806,807 ; see S. REP. No. 242, 98th Cong., 1st Sess. 10, reprinted in 1983 U.S. Code Cong. \& AD. News 1230, 1239 (first time Congress has considered specific authorization pursuant to War Powers Resolution); see also infra pp. 1332-33 (discussing political context of 


\section{B. The Responses of the Executive Branch}

The War Powers Resolution has yet to be accepted by the executive branch. President Nixon vetoed the bill on the ground that the restrictions which it would impose on the President's authority were "both unconstitutional and dangerous."11 After the Mayaguez Incident in 1975, the Ford Administration argued before a House subcommittee that section 2(c), the concurrent-resolution mechanism, and the sixty-day limitation were all unconstitutional. ${ }^{12}$ Two years later, the Carter Administration stated that the Resolution "raises a few questions under the Constitution" regarding its compatibility with the President's authority as Commanderin-Chief. ${ }^{13}$

The Reagan Administration has not conceded that the Resolution is constitutional. While President Reagan has submitted a number of reports to the Speaker of the House regarding specific deployments of U.S. forces abroad, ${ }^{14}$ the reports state only that their submission is "consistent with" the Resolution, not "pursuant to" or "under" the Resolution. This phrasing has left members of Congress uncertain as to the Administration's views. ${ }^{15}$ The Administration's unwillingness to invoke the Resolution following attacks on U.S. marines in Lebanon led to an impasse with congressional Democrats in September $1983^{16}$ resolved by passage of the

\section{3 resolution).}

11. Veto of the War Powers Resolution, PuB. PAPERs, Oct. 24, 1973, at 893. Nixon asserted that the concurrent resolution and sixty-day cut-off provisions were unconstitutional and "clearly without force." Id.

12. War Powers: A Test of Compliance Relative to the Danang Sealift, the Evacuation of Phnom Penh, the Eviacuation of Saigon, and the Mayaguez Incident: Hearings Before the Subcomm. on International Security and Scientific Affairs of the House Comm. on International Relations, 94th Cong., 1st Sess. 90-91, 95-97 (1975) [hereinafter cited as War Powers Hearings]. The Mayaguez incident led to military hostilities with Cambodia, without prior congressional authorization, in order to rescue the crewmen of an American freighter seized by Cambodia.

13. 123 Cong. Rec. 21,898 (1977) (written statement of Dep't of State). The Administration stated that, although "questions are presented" by the concurrent-resolution mechanism and the sixtyday limitation, "these questions would become real issues only in the event of a confrontation between the President and the Congress in a given case-an event which is not anticipated." Id. For a review of the Carter Administration's approach to the war powers issue, see W. REVELEY, WAR PowERS OF the President and Congress: Who Holds the Arrows and Olive Branch? 257-61 (1981).

14. Sep Subcomm. on Int'l Sec. and Sci. Afr. of House Comm. on Foreign Aff., The War Powers Resolution, Resolution, Relevant Documents, Correspondence, Reports, 98th Cong., 1st Sess. 57-66, 84-85 (1983) [hereinafter cited as WAR Powers Documents] (President's reports with respect to deployments in the Sinai, Lebanon, Chad, and Grenada).

15. Id.; Grenada War Powers: Full Compliance Reporting and Implementation, Markup on H.R.J. Res. 402 Before the House Comm. on Foreign Affairs, 98th Cong., 1st Sess. 14-15 (1983) (statements of Reps. Zablocki, Bonker, \& Gilman).

16. On September 14, 1983, Senate Democrats adopted a statement calling on the President to send a report to Congress acknowledging that congressional approval would be necessary for the continued presence of U.S. marines in Lebanon. N.Y. Times, Sept. 15, 1983, at A1, col. 6. While Congress essentially agreed with the deployment of the marines, a constitutional confrontation between the Executive and the legislature arose over the issue of the President's prerogative to keep the marines there without statutory authorization. See N.Y. Times, Sept. 17, 1983, at 1, col. 6; Sept. 16, 1983, at 
Multinational Force in Lebanon Resolution, ${ }^{17}$ through which Congress itself invoked the War Powers Resolution. ${ }^{18}$ According to Secretary of State Shultz, the Lebanon resolution demonstrated bipartisan support for the Administration's policy but did not settle the executive and legislative branches' "important differences of principle with respect to the War Powers Resolution."19

\section{The Resolution under Attack}

Much of the controversy over the War Powers Resolution has centered on section 2(c). Confusion over the meaning of section 2(c) arises from the fact that the provision was a last-minute compromise worked out in conference committee. ${ }^{20}$ Some observers view section $2(\mathrm{c})$ as a complete and binding enumeration, and argue that it is an overly restrictive statement of the President's power to use military force abroad. As the Ford Administration maintained, it may well be impossible to specify in advance all situations in which the President has the constitutional power to use force

A1, col. 6. The White House apparently feared that if the President accepted the provisions of the War Powers Resolution without reservation, he would lose the flexibility needed to deal with military confrontations abroad. Smith, War Powers Dispute, N.Y. Times, Sept. 17, 1983, at 4, col. 1.

17. Pub. L. No. 98-119, 97 Stat. 805 (1983).

18. Id. § 2. The Resolution states:

The Congress determines that the requirements of section 4(a)(1) of the War Powers Resolution became operative on August 29, 1983. Consistent with section 5(b) of the War Powers Resolution, the purpose of this joint resolution is to authorize the continued participation of United States Armed Forces in the Multinational Force in Lebanon.

Id. $\S 2$ (b). The accompanying Senate Report described the Resolution as "the reflection of a delicate compromise, carefully constructed in recognition of the firmly-held positions of both the legislative and executive branches." S. REP. No. 242, 98th Cong., 1st Sess. 14, reprinted in 1983 U.S. CodE ConG. \& AD. News 1230, 1243.

19. 129 Cong. Rec. E4427, E4428 (daily ed. Sept. 21, 1983) (statement of George P. Shultz, Secretary of State). Shultz went on to explain:

The Executive Branch has traditionally had questions about the requirement of Congressional authorization for Presidential disposition of our armed forces, both in light of the President's Commander-in-Chief power and on practical grounds. Congress, of course, has had a different view. We could not expect to resolve this basic difference definitely now . . . .

Id. For a review of the war powers controversy of late 1983, see Carter, The Constitutionality of the War Powers Resolution, 70 VA. L. REv. 101, 104-07 (1984).

20. Senator Fulbright, a member of the conference, reported to the Senate that the greatest difference between the House and Senate views had concerned $\$ 2(c)$, but that finally a "reasonable compromise" had been reached. 119 CoNG. REc. 33,548 (1973).

The Senate bill, S. 440, 93d Cong., 1st Sess., specified in \$ 3 (entitled "Emergency Use of the Armed Forces") the conditions under which armed forces could be introduced into hostilities or into situations where hostilities were imminent. The bill provided that the use of armed forces under any of those conditions had to be terminated within $\mathbf{3 0}$ days, unless Congress specifically authorized their continued use or the President certified in writing that their continued use was necessary for the safety of the armed forces during their disengagement from hostilities. 119 CoNG. REc. 25,119 (1973). The House version, H.R.J. Res. 542, 93d Cong., 1st Sess., in contrast, did not codify the circumstances under which the President could commit forces abroad without a declaration of war. Instead, it called for the termination of any commitment within 120 days unless Congress enacted specific authorization. Id. at 24,681-82. 
without congressional authorization. ${ }^{21}$ Scholars have argued that the limitation is also bad policy, since it would prevent the President from reacting immediately even to attacks on Canada or Mexico ${ }^{22}$ and casts doubt upon his authority to carry out American commitments under existing treaties. ${ }^{23}$ The Ford Administration, supported by scholars, also asserted that because the Resolution did not delegate any congressional power to the President, ${ }^{24}$ a concurrent resolution would not be binding on him ${ }^{25}$ and insisted further that, by limiting the President's unilateral use of force

21. War Powers Hearings, supra note 12, at 90-91 (statement of Monroe Leigh, Legal Adviser, Dept. of State) (no list could include all situations in which President may exercise his authority as Commander-in-Chief); see Rostow, Great Cases Make Bad Law: The War Powers Act, 50 TEx. L. REv. 833, 842-43 (1972) (not possible to meet all likely contingencies safely by codifying arrangements relating to conduct of foreign policy, especially with regard to use of nuclear weapons). The Carter Administration's position was that, while the President's authority as Commander-in-Chief to initiate hostilities without prior approval of Congress "has never been fully delineated," that authority does include the use of military force to protect the lives of U.S. nationals abroad. 123 CoNG. REC. 21,898 (1977) (written statement from Dep't of State). In 1980, President Carter stated that he had ordered the military expedition to rescue the American hostages held in Iran, which had not been authorized by Congress, pursuant to his powers as Chief Executive and as Commander-in-Chief. Rescue Attempt for American Hostages in Iran, 16 WeEkLY CoMP. Pres. Doc. 779 (Apr. 27, 1980). Similarly, in 1983, President Reagan stated that he had introduced U.S. forces into Grenada "pursuant to [his] constitutional authority with respect to the conduct of foreign relations and as Commander-in-Chief." WAR Powers Documents, supra note 14, at 85.

22. King \& Leavens, Curbing the Dog of War: The War Powers Resolution, 18 Harv. INT'L L.J. 55, 80-81 (1977); Reveley, The Power to Make War, in The Consrrrurion and the ConDUCT of Foreign Policy 83, 116-17 (F. Wilcox \& R. Frank eds. 1976); see Kelly, Proposed Legislation Curbing the War Powers of the President, 76 Dick. L. Rev. 411, 415-16 (1972) (proposed Senate bill of doubtful constitutionality because it did not recognize President's emergency power to repel attacks on foreign allies).

On its face, $\$ 2$ (c) seems to require the President to obtain a declaration of war or specific statutory authorization before using military force to defend Canada, unless an attack on Canada involves attacks on U.S. armed forces stationed there. See Franck, After the Fall: The New Procedural Framework for Congressional Control ovter the War Power, 71 AM. J. INT'L L. 605, 636 (1977). Presumably, the President could act only for the purpose of safeguarding U.S. armed forces, not for the purpose of defending Canadian sovereignty.

23. Section $8(a)(2)$ of the Resolution provides that authority to use military force shall not be inferred from any treaty unless it is implemented by legislation "intended to constitute specific statutory authorization within the meaning of [the Resolution]." 50 U.S.C. $\S 1547(a)(2)$ (1976). Thus, the NATO treaty does not constitute "specific statutory authorization" enabling the President as Commander-in-Chief to introduce forces into hostilities. Franck, supra note 22, at 634-37; see Rostow, supra note 21 , at $837-38$ (proposed Senate bill would annul military provisions of treaties).

24. Section $8(d)(2)$ states that nothing in the Resolution "shall be construed as granting any authority to the President with respect to the introduction of United States Armed Forces into hostilities ... which authority he would not have had in the absence of [the Resolution]." 50 U.S.C. \$ 1547(d)(2) (1976).

25. War Powers Hearings, supra note 12, at 96-97 (statement of Monroe Leigh, Legal Adviser, Dept. of State); see Cruden, The War-Making Process, 69 MrL. L. REv. 35, 103-07 (1975); cf. Scigliano, The War Powers Resolution and the War Powers, in The Presidency in THE ConstituTIONAL ORDER 115, 147-48 (J. Bessette \& J. Tulis eds. 1981). It would follow that, to effect the removal of forces committed to hostilities by the President, Congress would have to pass a statute subject to presidential veto. War Powers Hearings, supra note 12, at 91 (statement of Leigh). A more extreme position is that Congress may control the President's discretion to use military force abroad only by reducing funds for defense programs or by impeaching the President. Emerson, The War Pouers Resolution Tested: The President's Independent Defense Power, 51 Notre DAME LAw. 187, 214-15 (1975). 
to sixty days, the Resolution unconstitutionally infringed upon his warmaking power. ${ }^{28}$ The argument against the constitutionality of the concurrent-resolution provision has gained new force since the Supreme Court's decision in Immigration $\mathcal{\Xi}^{3}$ Naturalization Service $v$. Chadha. ${ }^{27}$

Starting from the view that section 2(c) had no binding effect on the President, several members of Congress attacked the Resolution at the time of its passage from the opposite angle-as unconstitutionally delegating Congress' warmaking power to the President. ${ }^{28}$ Indeed, if the power to initiate hostilities is one of Congress' "essential legislative functions," it may not be delegated to the President ${ }^{29}$-or at the very least, not "without standards for use in the future in indefinite circumstances."

In fact, Congress does not seem to have intended section 2(c) to impose an effective limitation on the President's discretion to introduce armed forces into hostilities without statutory authorization. ${ }^{31}$ At the same time,

26. War Pouters Hearings, supra note 12, at 95 (exchange between Leigh \& Rep. Solarz); Cruden, supra note 25, at 108 (Congress cannot accomplish by inaction what it cannot accomplish by affirmative action); see Emerson, supra note 25, at 211-13 (Congress may not impose geographical or time limitations on President's power to station troops as he deems appropriate).

27. 103 S. Ct. 2764 (1983) (discussed infra pp. 1349-50.

28. 119 Cong. Rec. $33,556,33,870,33,872$ (1973) (statements by Sen. Eagleton \& Reps. Abzug \& Holtzman). Senator Eagleton maintained that the Resolution was "an open-ended, blank check for 90 days of warmaking, anywhere in the world . . . ." Id. at 33,556. Similar arguments were advanced in the House debate. Id. at 33,870, 33,872 (statements by Reps. Abzug \& Holtzman).

29. A.L.A. Schechter Poultry Corp. v. United States, 295 U.S. 495, 529 (1935) ("The Congress is not permitted to abdicate or to transfer to others the essential legislative functions with which it is . . vested."); United States v. Gordon, 580 F.2d 827, 839 (5th Cir. 1978) (applying Schechter).

30. Bickel, Congress, the President and the Power to Wage War, 48 CHI.-KENT L. REv. 131, 137 (1971); see Scigliano, supra note 25, at 148; Wormuth, supra note 3, at 685, 692-94 (1972) (Congress must make policy determinations itself and may delegate only task of applying policy by making detailed rules or by finding facts that trigger contingent legislation). Bickel and Wormuth argue that the Tonkin Gulf resolution, Pub. L. No. 88-408, 78 Stat. 384 (1964), read broadly, constituted an unconstitutional delegation of the power to make war. Bickel, supra, at 136-39; Wormuth, supra note 3, at 690-97.

31. First, the statement of the conference committee that, in contrast to the Senate bill, subsequent sections of the Resolution are "not dependent upon the language" of $\S 2$ (c), see Joint Explanatory Statement of the Committee of Conference, 119 CoNG. REC. 33,037 (1973), seems to indicate that the legislators anticipated uses of force by the President that do not come under any of the categories in $\$$ 2(c). Congress, therefore, seems to have made a conscious distinction between the Senate bill, which did appear to contemplate an effective limitation on the President's discretion in the absence of statutory authorization, and the Resolution that was finally agreed upon. The sections of the Senate bill subsequent to $\S 3$ ("Emergency Use of the Armed Forces") dealt with the reporting, authorization, and termination of the use of the armed forces in hostilities. Each section stated that it applied to the use of armed forces "under any of the conditions described in section 3." Since the conditions described in $\S 3$ encompassed the most serious national emergencies that could possibly occur, the fact that subsequent sections limiting presidential discretion were intended to apply only to those conditions implied that under no other conditions was the President to act without a declaration of war. 119 ConG. REC. at 25,119-20 (1973); see id. at 33,556 (statement of Sen. Eagleton); id. at 33,871 (statement of Rep. Dellums).

Second, § 2(c) was included under "Purpose and Policy," 50 U.S.C. § 1541 (1976), which implies that it was not meant to be an operative provision. Quoting from a "hornbook," Senator Eagleton argued during the Senate debate that the section was not "operative" because a policy section "cannot be given the effect of enlarging the scope or effect of a statute." 119 CoNG. REC. 33,559 (1973). Instead, according to Eagleton, §2(c) represented a "'sense of Congress' interpretation of the Presi- 
the Resolution purports not to grant any authority to the President. ${ }^{32}$ As a result, the Resolution does not appear to have altered the executive's power to initiate American involvement in hostilities without prior authorization. Only reference to the constitutional restrictions on the President's war powers can determine the President's present authority in this regard. In addition, an examination of the constitutional sources of the executive's war powers sheds light on the legality of the concurrentresolution mechanism and the sixty-day limitation.

\section{The Extent of the President's War Powers}

The President's "war powers" refers to two distinct though partly overlapping powers: a broad "executive power," which is amenable to legislative control, and a rather narrow commander-in-chief power, which Congress may not curtail. This Note argues that the President's discretion to initiate involvement in hostilities is based on the vesting of "executive power" in the President. ${ }^{33}$ Accordingly, this authority is subject to the same restraints that apply to other types of executive action in an emergency. Thus, while the President may sometimes initiate involvement in hostilities when Congress is silent, Congress may terminate such involvement by concurrent resolution.

\section{A. The Constitutional Sources of the President's War Powers}

The delegates to the 1787 Convention were overwhelmingly opposed to giving the executive branch the power of "war and peace." 34 They gave

dent's powers." Id. at 33,556. Senator Javits countered that all sections of the Resolution were operative, irrespective of their headings. Id. at 33,559. In 1975, Representative Zablocki, who had sponsored the Resolution in the House and had participated in the conference, testified that "Ii]n order to satisfy the Senate conferees, we agreed to section 2(c) but it was intended as a statement of purpose and policy, a sort of sense of Congress." War Powers Hearings, supra note 12, at 32.

Finally, the fact that $\S 2$ (c) does not mention the power to use armed forces to evacuate American citizens in danger abroad, which was included in the Senate bill as one of the circumstances justifying the introduction of armed forces into hostilities, suggests that $\S 2(\mathrm{c})$ was not intended to be a complete enumeration of the circumstances in which the President could use military force. See 119 Cong. REC. 33,558 (1973) (remarks of Senator Eagleton). Senator Javits reported that the power to evacuate nationals was omitted from $\S 2$ (c) "in order to be conservative in respect of the President's power." Id. He added that the President could always assert such authority regardless of what the Resolution said. Id. at 33,559 .

32. See supra note 24.

33. Cf. Note, Congress, the President, and the Power to Commit Forces to Combat, 81 HARv. L. REv. 1771, 1775 (1968) (purposes for which President may exercise commander-in-chief power "must ultimately be found in other provisions of article II" than commander-in-chief clause).

34. Charles Pinckney (the Younger) argued that giving the Executive the power of war would make it "a Monarchy, of the worst kind, to wit an elective one." 1 THE RECORDS OF THE FEDERAL Convention of 1787, at 65 (M. Farrand ed. 1911) [hereinafter cited as FARRAND ReCordS]. Rutledge and Mason also expressed opposition to vesting the power of war in the Executive. Id. (Rutledge); $2 \mathrm{id}$. at 319 (Mason). Gerry said that he "never expected to hear in a republic a motion to empower the Executive alone to declare war." Id. at 318. Madison later described war as "the true 
Congress the power to declare war $^{35}$ and intended not only that the legislature make formal declarations of war but that it have actual control over the decision to go to war. ${ }^{36}$ Notwithstanding Congress' power to declare war, the President has the authority to initiate the use of military force in an emergency. This power derives not from his role as Commander-inChief, as is commonly believed, but from the general grant of executive power to the President.

The Framers did not intend the President's power as Commander-inChief to include the power to initiate U.S. involvement in hostilities abroad. Rather, the Framers made him Commander-in-Chief to ensure that the nation's military forces were under civilian control ${ }^{37}$ and under the direction of a single individual. ${ }^{38}$ The President's authority, according to Hamilton, "would amount to nothing more than the supreme command and direction of the military and naval forces, as first general and admiral of the Confederacy .... ."39

Historical practice, beginning with measures taken by Lincoln during the Civil War, has arguably transformed the commander-in-chief power into a "vast reservoir of indeterminate powers in time of emergency." 40 Nonetheless, the President's purported role as "constitutional dictator"41

nurse of executive aggrandizement." Letters of Helvidius (1793), reprinted in 6 THE WRITINGs of James Madison 138, 174 (G. Hunt ed. 1906) [hereinafter cited as Madison Writings]. He wrote that the executive branch was the one with the greatest "propensity to war" and that no one man could be trusted with the war power. Id.

35. U.S. ConST. art. I, $\S 8$, cl. 11.

36. Jefferson wrote that the transfer of the war power to the legislature constituted an "effectual check to the Dog of war." Letter to James Madison, Sept. 6, 1789, reprinted in 15 ThE PAPERS oF Thomas JefFerson 392, 397 (J. Boyd ed. 1958). Madison maintained that the clause confiding "the question of war or peace to the legislature" was one of the wisest in the Constitution. 6 MADIsoN WRITINGS, supra note 34, at 174.

37. One of the charges set forth in the Declaration of Independence was that the King "affected to render the Military independent of and superior to the Civil Power." The Declaration of Independence para. 14 (U.S. 1776); see also E. KEYNES, UNDECLARED WAR 165 (1982) (Framers made uniformed military services directly accountable to President who "is accountable to American people for the higher direction of war").

38. In defending the commander-in-chief clause, Hamilton argued: "Of all the cares or concerns of government, the direction of war most peculiarly demands those qualities which distinguish the exercise of power by a single hand." The Federalist No. 74, at 447 (A. Hamilton) (Mentor ed. 1961). The Framers were probably influenced by Montesquieu, who had written that an army would not respect orders sent by a legislative body. C. MONTEsquiEU, THE SPIRIT OF LAws at 212 (Carrithers ed. 1977).

39. The Federalist No. 69, at 418 (A. Hamilton) (Mentor ed. 1961). Hamilton noted that, in contrast, the British king had the power to raise armies and declare war.

40. E. Corwin, The President: Office and Powers 1787-1957, at 261 (4th ed. 1957). Presidents Lincoln, Wilson, and Franklin Roosevelt invoked the commander-in-chief clause to justify a wide range of measures, not related to the direction of military forces, that were deemed necessary for the nation's war efforts. Id. at 227-34, 237, 242-58, 261-62; see C. Rossiter, Constitutional DicTATORSHIP 217 (1948) ("realities of government" place power to declare martial law in hands of President as Commander-in-Chief). Indeed, the clause has been described as an "elastic block" that expands "in the heat of war." Corwin, War, the Constitution Moulder, in Presidential Power AND THE CONSTITUTION 23, 23 (R. Loss ed. 1976).

41. C. Rossiter, The American Presidency 25 (2d ed. 1960). 
once wars have begun does not empower him to commence the wars himself. For as Madison noted in 1793, one must carefully distinguish the power that a commander-in-chief has "to conduct a war" from the power to decide "whether a war ought to be commenced, continued, or concluded." "12

The President's power to initiate the use of force abroad during crises is based rather on his "executive power." This grant gives him discretion to take necessary actions without statutory authorization in emergencies for which Congress has provided no directions in advance. Accordingly, in a military emergency, the President may introduce U.S. armed forces into combat abroad without prior authorization from Congress.

\section{The Framers' Intent}

The Framers viewed the vesting of executive power in the President as a broad grant of authority. Hamilton emphasized that in contrast to Article I, which vests the "legislative Powers herein granted" in Congress, ${ }^{43}$ Article II provides that "[t]he executive Power shall be vested" in the President. ${ }^{44}$ Thus, while the Framers limited Congress' powers to legislate to those enumerated in section 8 of Article I, they granted the President the entire "executive power" as understood by the Framers, ${ }^{45}$ subject

42. 6 MAdison WRITINGs, supra note 34 , at 148 (emphasis in original). Madison argued that both powers could not be exercised by the same branch because of their "incompatibility." Id.

43. U.S. ConST. art. I, § 1.

44. U.S. ConsT. art. II, $\S 1$, cl. 1.

45. See Pacificus No. I, June 29, 1793, reprinted in 15 The Papers of Alexander Hamilton 33, 38-40 (H. Syrett ed. 1969) [hereinafter cited as HAMmton PAPERs]. Writing in defense of President Washington's Proclamation of Neutrality, Hamilton argued that the powers of the President enumerated in $\$ \S 2$ and 3 of Article II were not intended to be "a complete and perfect specification" of the executive's authority. Id. at 39. Rather, the enumeration was meant to specify only the "principal articles" of the executive power, "leaving the rest to flow from the general grant of that power ...."Id. This construction of Article II is the basis of the "residual power doctrine," which states that the President has "all executive power necessary to preserve and protect the sovereignty and integrity of the nation." Gibson, The President's Inherent Emergency Powers, 12 FED. B.A.J. 107, 111-12 (1951).

The original wording for Article II considered by the Convention delegates was "a national Executive . . . to possess the executive powers of Congress." 1 FARRAND RECORDS, supra note 34, at 64. Charles Pinckney (the Younger) expressed concern that such powers "might extend to peace \& war." $I d$. at 64-65. His comment lends credence to Hamilton's assertion that the grant of executive power was meant to be general. Madison's proposal that the clause read "that a national Executive . . . be instituted with power to carry into effect the national laws" would not have permitted a broader vesting of power to be inferred. Id. at 67.

Quoting Hamilton at length, the Supreme Court has accepted the view that the Framers did not confine the "general grant of executive power" to the specific powers mentioned in Article II and has held that "the fact that no express limit was placed on the power of removal [of executive subordinates] by the Executive was convincing indication that none was intended." Myers v. United States, 272 U.S. 52, 118, 137-39 (1926). But cf. Youngstown Sheet \& Tube Co. v. Sawyer, 343 U.S. 579, 641 (1952) (Jackson, J., concurring) (clause not "a grant in bulk of all conceivable executive power" but rather "an allocation to the presidential office of the generic powers thereafter stated"); E. KEYNES, supra note 37, at 51-52 (constitutional text and Convention debates do not resolve controversy over scope of executive power); Berger, The Tug-of-War Between Congress and the Presi- 
only to the express qualifications in the Constitution. ${ }^{16}$ In effect, the Framers contemplated that the President's authority would extend to those powers which by their nature were executive. ${ }^{47}$

The writings of Locke and Montesquieu undoubtedly influenced the Framers' conception of the nature of "executive power." In The Second Treatise of Government, Locke wrote of the "prerogative" of the executive power "to act according to discretion for the public good, without the prescription of the law" in certain circumstances where the "law has given no direction." $49 \mathrm{He}$ went on to argue that, at times, the "prerogative" includes the power to act "against the direct letter of the law, for the public good ...." With respect to the use of military force, Montesquieu

dency-Foreign Policy and the Power to Make War, 16 WASHBURN L.J. 1, 4-5 (1976) (specific enumeration of powers in Article II indicates extent of executive power).

46. 15 Hamilton PAPERS, supra note 45, at 39-40. Hamilton noted three exceptions in the text of the Constitution to the vesting of executive power in the President: the Senate's participation in appointing officers and in making treaties, and "the right of the Legislature 'to declare war and grant letters of marque and reprisal." Id. at 39.

47. At the Convention, Madison stated that "certain powers were in their nature Executive" and had to be vested in the executive branch. 1 FARRAND RECORDS, supra note 34, at 66-67. Another delegate (Wilson) observed that the extent of the executive power should not be based on the "Prerogatives of the British Monarch," since certain of those prerogatives, such as the power over "war \& peace," were "of a Legislative nature." Id. at 65-66.

In Pacificus No. I, Hamilton maintained that whether the President had the authority to issue a proclamation of neutrality depended on the "nature and design" of such a proclamation. 15 HamiLTON PAPERS, supra note 45, at 34 . He concluded that the making of a declaration of neutrality did not "naturally" belong to the legislature and was "foreign to the Judiciary Department"; hence, it was a function of the executive. Id. at 37-38. Madison's response to Hamilton was not that the President did not have those powers that were executive in nature, but that the powers of "making war and treaty being substantially of a legislative, not an executive nature," the related power of "judging . . . the obligations to make war" belonged to the legislature. 6 MADISON WRITINGS, supra note 34, at 145-46, 153; see Scigliano, supra note 25, at 127-33 (reviewing Hamilton's and Madison's arguments). Apparently, Madison was willing to concede that if a power was executive in nature, it belonged to the Executive unless the Constitution explicitly provided otherwise.

48 Jefferson relied heavily on Locke's philosophy in writing the Declaration of Independence. See Peardon, Introduction to J. Locke, The Second Treatise of Government at xix-xx (T. Peardon ed. 1952). Moreover, passages from Locke's writings were read aloud at the Convention. 1 FARRAND RECORDS, supra note 34, at 437-38. Montesquieu's The Spirit of Laws was widely read in late 18 th-century America. Carrithers, Preface to C. Montesquieu, supra note 38, at xiii. Hamilton and Madison each quote Montesquieu twice in the Federalist Papers. THE Federalist No. 9, at 74 (A. Hamilton) (Mentor ed. 1961); id. No. 78, at 466 n.*; id. No. 43, at 275 (J. Madison); id. No. 47 , at 302-03.

49. J. LockE, supra note 48, at 91-92. Locke wrote that "prerogative" is necessary since in some governments the lawmaking power is not always in being, and is usually too numerous and so too slow for the dispatch requisite to execution, and because also it is impossible to foresee, and so by laws to provide for, all accidents and necessities that may concern the public....

Id. at 92. Thus, the prerogative served to ensure that the slowness of the legislative process never jeopardized the well-being of the community.

50. Id. at 93-94. Locke justified his view on the ground that "it is impossible . . to make such laws as will do no harm if they are executed with an inflexible rigor on all occasions and upon all persons that may come in their way ...."Id. at 92. The examples that Locke offered were the pulling down of a house to keep a fire from advancing and the pardoning of certain offenders. Id. at 91. Leaving aside the power to pardon, it is apparent that Locke was afraid that the law might stand in the way of necessary action in an emergency. Clearly, he was not advocating a general prerogative 
maintained that the army "from the very nature of the thing" should be controlled by the executive power. ${ }^{.1}$

The Convention delegates, however, disputed that the power over war and peace was executive in nature. ${ }^{\mathbf{2}}$ While they were not all of the opinion that it was of a legislative nature, ${ }^{53}$ they decided not to vest it in the executive. ${ }^{54}$ By giving the legislature the power to "declare" war rather than to "make" war, however, the Framers left in the President's hands "the power to repel sudden attacks." conduct a war forced on the United States-as opposed to the power to decide the policy question of whether to go to war with a foreign power-as part of the executive function.

\section{Judicial Precedent}

Given the President's role as protector of the nation from outside attack, ${ }^{58}$ the President must have been understood to have the power to respond to sudden attack even without statutory direction. ${ }^{57}$ Of course, since a sudden attack necessarily forces a state of war on the nation, presiden-

of the executive power to disregard any laws that the ruler considers bad.

51. C. MontesQuieu, supra note 38, bk. XI, ch. 6, at 212. Montesquieu observed that an army's "business consist[s] more in action than in deliberation"; hence, it should not answer to the legislature. Id. To prevent the executive power from abusing its control of the armies, he proposed that the legislative body have the authority to disband the armies at any time, and that the soldiers "have the same spirit as the people" and not live in separate quarters. Id. Apparently, whenever armies were in being, the executive power was to have full discretion over how they were to be used.

52. 1 FARRAND Records, supra note 34, at 65-66 (Wilson's statements); 6 MAdISON WRITINGS, supra note 34, at 145-51. Both Madison and Wilson saw the power of war as legislative in nature.

53. Hamilton considered the right to declare war to be a portion of the "Executive Power of the Nation" reserved for Congress by the Constitution. 15 HAMILTON PAPERS, supra note 45, at 39-40. Charles Pinckney (the younger) was uncertain whether the "Executive powers" included those of "peace \& war." 1 FARRAND RECORDS, supra note 34, at 64-65.

54. See supra pp. 1336-37.

55. 2 FARRAND RECoRds, supra note 34, at 318. This construction was the basis of the motion by Madison and Gerry to change the wording of the clause from "To make war" to "To declare war." Id. The Framers were well aware of the possibility of the Executive having to conduct an undeclared war. Hamilton observed that "[a]s the ceremony of a formal denunciation of war has of late fallen into disuse," the United States had to be able to raise armies "in time of peace" for it to prepare against an anticipated invasion. The Federalist No. 25, at 165 (A. Hamilton) (Mentor ed. 1961).

56. Hamilton argued that a "vigorous executive" was necessary for protection from invasion. THE Federalist No. 70, at 423 (A. Hamilton) (Mentor ed. 1961).

57. Hamilton wrote that the functions of the Executive were "the execution of the laws and the employment of the common strength, either for this purpose or for the common defense." Id. No. 75, at 450. Thus, the President could exercise his power to use military strength "for the common defense" independently of his power to execute the laws. One can also infer this proposition from the principle that "the persons from whose agency the attainment of any end is expected [such as protection from invasion] ought to possess the means by which it is to be attained." Id. No. 23, at 153 (emphasis in original). Ten years later, Hamilton argued that once Tripoli had declared war on the United States, the President, without "the sanction of Congress," could order the navy to capture enemy ships and hold their crews. AleXander Hamilton and the Founding of THE Nation 209 (R. Morris ed. 1957) (emphasis in original). 
tial conduct of war in such circumstances is justified under both the commander-in-chief power and the "executive power."" The Supreme Court upheld the President's power in the absence of "special legislative authority" to conduct a war initiated by an enemy invasion or an insurrection in the Prize Cases. ${ }^{\text {.8 }}$

Although the Supreme Court's opinions support the Lockean view that the President has the power to respond to a crisis when Congress has provided no statutory guidance, they deny his authority to disregard procedures provided by Congress for dealing with a particular kind of emergency. ${ }^{60}$ The clearest expression of judicial support for the President's power to act for the public good in the absence of statutory authorization is found In re Neagle, ${ }^{61}$ which reviewed executive action taken to protect a federal judge. The majority opinion emphasized that the President's duty to execute the laws was not "limited to the enforcement of acts of Congress . . . according to their express terms," but rather extended to "all the protection implied by the nature of the government." ${ }^{\text {" S2 }}$ Similarly,

58. See supra pp. 1337-38.

59. 67 U.S. (2 Black) 635, 668-69 (1862). The Court stated that, while the President may not initiate a war against a state or a foreign nation, in the event of a rebellion by states or an invasion by a foreign nation the President is "bound to resist force by force." Id. at 668 .

60. In Little v. Barreme, 6 U.S. (2 Cranch) 170 (1804), the relevant statute had suspended all commerce between the United States and France. Chief Justice Marshall stated that it was "by no means clear, that the President . . . might not, without any special authority for that purpose" have ordered the seizure of vessels on the high seas bound from a French port. Id. at 177. The Chief Justice then noted that the fifth section of the statute gave "a special authority to seize on the high seas," but limited the authority to ships on their way to France. Id. He concluded that "the legislature seem to have prescribed that the manner in which this law shall be carried into execution, was to exclude a seizure of any vessel not bound to a French port." Id. at 177-78 (emphasis in original). Thus, where Congress has chosen a particular means of executing a statute, implicitly rejecting all other means, the President's power to execute the laws does not give him the prerogative to carry out the statute by any means other than the one Congress has laid down. It follows that when the President is simply responding to an emergency, he must adhere to the means provided by Congress for dealing with that type of emergency.

61. 135 U.S. 1 (1890).

62. Id. at 64 (emphasis added). Justice Miller ruled that the President may order protection for a federal judge in danger of violent attack even if Congress has passed no law providing for such action. Id. at 67. His opinion approvingly recalled an historical precedent involving action taken abroad without statutory authorization. A Hungarian who had declared his intention to become an American citizen was seized in Smyrna and taken aboard an Austrian ship. The commander of an American warship also in port demanded that the prisoner be turned over to him and had his ship's guns trained on the Austrian vessel. As a result, the Austrians surrendered the Hungarian to the custody of the French consul, pending the outcome of diplomatic negotiations. After recounting the incident, Justice Miller asked: "Upon what act of Congress then existing can any one lay his finger in support of the action of our government in this matter?" Id. at 64. The Court also cited Wells v. Nickles, 104 U.S. 444 (1881), for the proposition that, even without statutory authorization, the Department of the Interior can instruct its agents to seize timber cut on United States lands and thereby act to protect "valuable public property." 135 U.S. at 65-66. Thus, Neagle was a broad holding that the Executive, under a wide range of circumstances, could act for the public good in the absence of law. But see Youngstown Sheet \& Tube Co. v. Sawyer, 343 U.S. 579, 587 (1952) ("President's power to [execute laws faithfully] refutes the idea that he is to be a lawmaker") (discussed infra note 67). 
the Court in United States v. Midwest Oil Co. ${ }^{63}$ upheld the President's withdrawal of oil-rich public land that Congress had opened to exploration and location. The opinion stated that in an emergency the President, as "agent," can withhold land from acquisition even if Congress has not granted him express authority to do so. ${ }^{64}$

Youngstown Sheet E Tube Co. v. Sawyer ${ }^{\mathrm{BS}}$ presents the most thorough treatment of the extent of the President's emergency power. The concurring opinions of Justices Frankfurter, Burton, and Glark carefully distinguished between emergency situations for which Congress has provided procedures in advance and emergency situations not covered by any statute. While agreeing with the opinion of the Court that the President did not have the power to seize the steel mills to avert a strike, the three Justices stressed that the procedures laid down by Congress for dealing with a threatened walk-out did not include seizure. ${ }^{66}$ Justice Clark stated that when there is no "such action by Congress, the President's independent power to act depends upon the gravity of the situation confronting the nation." $"$ 67

63. 236 U.S. 459 (1915).

64. Id. at 474. The opinion noted that a report of the Director of the Geological Survey, on the basis of which the withdrawal of lands had been ordered, had stated that if private parties continued to patent California oil lands at the same rate, the United States would lose all its remaining oil lands in a matter of months. The report had concluded that there was an "immediate necessity" to conserve these lands if the Government were to have oil left for its own use. Id. at 466-67. Thus, the situation did present an emergency.

The precise holding of the Court was not that the President could act in the absence of any grant of authority, but that congressional acquiescence with respect to previous withdrawals of public land had resulted in "an implied grant of power" to take such action in "the public interest." Id. at 475; see Dames \& Moore v. Regan, 453 U.S. 654, 686 (1981) (congressional consent inferred from acquiescence in long-continued practice). The creation of an implied grant of power out of congressional acquiescence in a particular executive practice, however, presupposes some discretion on the part of the President, at least in the short run, to act even when there has been no grant of power, express or implied.

65. 343 U.S. 579 (1952).

66. Justice Frankfurter stated: "We must . . . put to one side consideration of what powers the President would have had if there had been no legislation whatever bearing on the authority asserted by the seizure . . ." Id. at 597 (Frankfurter, J., concurring). He went on to argue that with the passage of the Labor Management Relations Act of 1947, "seizure as an available remedy for potential dangers was unequivocably put aside." Id. at 599-600. Justice Burton distinguished the case "from one in which Congress takes no action and outlines no governmental policy." Id. at 659 (Burton, J., concurring). Citing Little v. Barreme, 6 U.S. (2 Cranch) 170 (1804) (discussed supra note 60), Justice Clark maintained that where Congress has provided "specific procedures to deal with the type of crisis confronting the President, he must follow those procedures in meeting the crisis . . . ." Id. at 662 (Clark, J., concurring in judgment).

67. Id. at 662. Justices Frankfurter and Burton, in contrast, did not discuss the extent of the President's discretion to act in an emergency for which Congress has provided no direction. The opinions of Justices Black, Douglas, and Jackson rejected the proposition that the President may take steps to deal with an emergency without statutory authorization. Justice Black, writing for the Court, stated that the seizure was not justified by the grant of executive power, because "the President's power to see that the laws are faithfully executed refutes the idea that he is to be a lawmaker." Id. at 587. While acknowledging that "the emergency may take its toll in ... war production ... and perhaps even lives" as the nation waited for congressional action, Justice Douglas argued that to 
In dissent, Chief Justice Vinson, joined by Justices Reed and Minton, defended the President's move as an effort to save legislative programs that were dependent on steel production "until Congress could act." dissent likened the seizure to "a judicial stay eniered to maintain the status quo in order to preserve the jurisdiction of a court."

The opinions in Youngstown indicate that four of the Justices (Vinson, Minton, Reed, and Clark) would have allowed the President to act in an emergency for which the law provided no direction, and three of the Justices (Black, Douglas, and Jackson) would have opposed such action. While Justices Frankfurter and Burton did not address the question, the fact that they distinguished between the case before them and the case in which Congress has provided no policy in advance suggests that they were at least open to the idea of presidential action without legislative authorization during periods of emergency.

\section{The Limits of the Executive Power}

While the Framers viewed a presidentially directed military response to a sudden attack on American territory as justified, it is doubtful whether they would have construed the executive power to allow the President to initiate the use of force abroad during crises. ${ }^{70}$ The problem with relying on the Framers' intent to resolve this question is that eighteenth-century

determine "[t]he method by which industrial peace is achieved" is to exercise the legislative power placed by the Constitution in Congress. Id. at 629-30 (Douglas, J., concurring). Justice Jackson noted that to "retain Government by law," Congress could grant "extraordinary authorities" in advance which could be invoked by the President in time of emergency but would "lie dormant in normal times." Id. at 652-53 (Jackson, J., concurring).

68. Id. at 683 (Vinson, C.J., dissenting). Although the dissent describes the action taken by the President as an attempt "to faithfully execute the laws," $i d$. at 703, the legislative programs said to justify the seizure were not ones for the production of steel but ones whose success depended on an adequate supply of steel. The Mutual Security Act of 1951, for example, provided for military and economic aid to foreign countries. Vinson noted that defense production in these countries was dependent on U.S. steel, implying that the seizure was simply a means of executing a foreign aid program. Id. at 670 . It would follow that, since the success of a foreign aid program depends on the continued functioning of the recipient nation, the President may "execute" the program by ordering military intervention whenever a recipient nation is threatened by invasion.

The other legislative program referred to by the dissent consisted of appropriations for military equipment requiring steel. Id. at 671. If preserving a supply of resources necessary for the armed forces is merely a way of executing defense programs, then military intervention to protect Persian Gulf oil would also come under faithful execution of the laws. Clearly, Chief Justice Vinson viewed the President as having the power to deal with "national emergencies" "[w]ith or without explicit statutory authorization." Id. at 683.

69. Id. at 703. The dissent argued that the President must be able to "act to preserve legislative programs from destruction so that Congress will have something left to act upon." Id. at 709 . It also asserted that "there is no basis for fear of dictatorship when the Executive acts . . only to save the situation until Congress could act." Id. at 704.

70. See Lofgren, War-Making Under the Constitution: The Original Understanding, 81 Yale L.J. 672, 699-701 (1972). As one Convention delegate argued, the President ought to have the power "to repel and not to commence war." 2 FARRAND ReCords, supra note 34, at 318 (Sherman's remarks). 
Americans could hardly have conceived of military events abroad as constituting a genuine emergency. To the extent that such events do present emergencies demanding immediate action, however, it is consistent with the Framers' intent to conclude that the President has constitutional authority to respond militarily, as long as Congress retains final decision on whether to continue military involvement. Thus, the ultimate power over war and peace will remain in the legislature, as intended by the Framers.

Neither the Framers' intent nor judicial precedent provides much guidance for distinguishing between those emergencies, if any, in which the President may commit military forces to combat abroad pending congressional action and those necessitating advance authorization from Congress. Recalling the Framers' concern with the dichotomy between powers that are "legislative" in nature and those that are "executive" in nature, however, one can consider under what conditions, given the current needs of foreign-policy decisionmaking, the decision to initiate American involvement in hostilities abroad in the absence of statutory authorization is "executive" in nature. If the objectives of dividing the war powers between legislature and executive would best be served by giving certain emergency authority to the executive branch, then that authority should be deemed "executive" in nature and vested in the President. ${ }^{\mathbf{7 2}}$

An optimal allocation of the war powers would both give the United States the capability to use force or the threat of force effectively to protect national interests ${ }^{73}$ and provide a sufficient degree of democratic control over the decision to go to war. ${ }^{74}$

The objective of effectiveness necessitates a division of authority that allows the government: (1) to order an immediate military response to an attack on American armed forces or on a vital interest of the United States; ${ }^{75}$ (2) to resort to military operations which must be kept secret

71. See supra pp. 1338-39.

72. But see Wilmerding, The President and the Law, 67 PoL. ScI. Q. 321, 324, 334 (1952) (President does not have legal power to act in emergencies; rather, "[i]mperious circumstances may sometimes require the high officers of government to act outside the law").

73. Professor Myres McDougal has written: "In a still primitively organized world in which expectations are low about the effective capability of the general community to protect its individual members, [the right of self-defense] has been regarded as indispensable to the maintenance of even the most modest minimum order." McDougal, The Soviet-Cuban Quarantine and Self-Defense, 57 AM. J. INT'L L. 597, 598 (1963). In this international environment, a state's very existence may depend on its capability to use military force effectively.

74. The objective of democratic control is based on the principle that democratic decisionmaking is good in and of itself, not that it will necessarily lead to better decisions. Each of the ends that the Framers appear to have had in mind in dividing the war powers between the legislature and the executive is included within the objectives of effectiveness or democratic control or a combination of the two. See W. REVELEY, supra note 13, at 175-81 (1981) (describing "war-power ends" of Framers and ratifiers); Reveley, supra note 22, at 91-95.

75. Some commentators have maintained that while the need for instant foreign policy decisions is frequently asserted, it "has not really existed." C. BLACK \& B. ECKhaRdT, TIDES of POWER 39-40 (1976). Some recent situations where speedy decisions by the U.S. Government were actually neces- 
until carried out; ${ }^{76}$ and (3) to deter enemy states and to assure friendly states by coordinating its diplomatic statements with uses of force short of war ${ }^{77}$ and by carrying out its threats and promises. ${ }^{78}$

The government will be better able to decide quickly on an appropriate military response in an emergency ${ }^{79}$ if it vests the power to initiate hostilities in a single individual who need not persuade others of the correctness of a particular course of action. ${ }^{80}$ The individual best suited for this role is

sary, however, include the brief periods in 1967 and 1973 when the Soviet Union appeared ready to intervene militarily in the Arab-Israeli wars. See Emerson, War Powers Legislation, 74 W. VA. L. REv. 53, 78-80 (1971).

76. The use of American aircraft in the successful rescue of 2,000 persons, including about 60 U.S. citizens, who were held hostage by a rebel force in the Congo in 1964 could not have been authorized in advance by Congress without letting the rebels know that such an operation was under way. Emerson, supra note 75 , at $81-83$. For the same reason, the attempt in 1980 to rescue the American hostages held in Iran had to be carried out without prior authorization.

77. The use of military force "without significant violence" is commonly viewed as just another instrument of foreign policy, like personal diplomacy or foreign aid. B. BLECHMAN \& S. KAPLAN, FORCE WITHOUT WAR 3-4 (1978). While the mere existence of U.S. armed forces and their routine movements play a continuous and decisive political role, the military is often called upon to carry out discrete actions in order to influence particular situations abroad. Id. at 11-12. By focusing the attention of foreign leaders on American military might, military movements and alerts serve to deter or compel actions by opposing states, and to assure or induce action by friendly states. Id. at 53, 72 .

78. Since World War II, advances in the technology of war-particularly in nuclear weapons-have rendered military "defense" beyond the capabilities of any state. As a result, the major powers have come to rely on "deterrent strategies," which involve the communication of threats of "punishment" to opposing states. See O. Young, The Politics of Force: Bargaining During INTERNATIONAL CRISEs 47 (1968). Successful deterrence requires the effective communication of "credibility, resolve, and political will." Id. During serious crises, diplomatic communications are likely to be used to mislead adversaries as to one's own motives, expectations, physical capabilities, and resolve. Id. at 39,117-18 \& n.1. In such circumstances, physical actions are especially valuable as means of "authenticating verbalized statements," thereby communicating resolve. Id. at 117-18, 142. Moreover, the transience of and uncertainty during a crisis tend to increase the value of demonstrations of resolve relative to the value of actual physical capabilities. See id. at 175 .

A state must have a reputation for truthfulness if it is to make effective threats. Once a state issues a threat, it fails to carry out its pledge only at the expense of its reputation for truthfulness. See $\mathrm{R}$. Jervis, The Logic of Images in International Relations 78, 82-84, 88 (1970). If the President were to threaten a particular response and be restrained by Congress from carrying it out, he would not be viewed by foreign leaders as a liar. Nevertheless, the "signals" he issued would be less credible in the future. See id. at 83-84.

A Brookings Institution study asserts that from 1946 to 1975, "positive outcomes" in the short term from discrete uses of American military force short of war were more frequent in regions where the U.S. recently conducted wars, such as in East Asia soon after the Korean War. B. BLeCHMAN \& S. KAPLAN, supra note 77, at 110 . Such effects are evidence of the importance of demonstrating resolve. Presumably, foreign leaders are more likely to believe threats if the U.S. has already displayed its willingness to engage in hostilities. See id. The importance of communicating determination is also supported by the finding that the less easily reversible a particular commitment of force is, the more likely it is to produce a favorable outcome. Id. at 529-30.

79. An "emergency" is defined here as "a situation that (1) threatens the high-priority goals of the decision-making unit [and] (2) restricts the amount of time available for response before the situation is transformed . . . " C. Hermann, Crises in Foreign Policy: A Simulation Analysis 29 (1969) (situational characteristics of crisis). Hermann states that a third attribute of a crisis is that it "surprises the members of the decision-making unit when it occurs." Id. This attribute is unnecessary for an "emergency," because its absence from a particular situation does not reduce the need for immediate action by the President.

80. W. Jennings, The BRITiSh Constitution 195-96 (1941) (ordinarily, war decisions can be made more efficiently by single person, like German Führer, than by committee, such as British 
the President, who, as commander of all the nation's armed forces, is in a position to take whatever military steps are needed to deal with a sudden attack $^{81}$ and to plan operations secretly. Furthermore, in view of the Executive's position as the nation's foreign policy spokesman, ${ }^{82}$ the coordination of diplomatic communications with military maneuvers requires that the President have discretionary power over the deployment of military forces, especially land-based forces, ${ }^{83}$ and that he have the capability to carry out the threats he makes. ${ }^{84}$

The goal of democratic control dictates, however, that a decision to commit the nation to a course of war, as opposed to the decision to begin using force in a particular instance, should not devolve upon any one individual, no matter how representative he is of the national electorate, but should be left to a legislative body. ${ }^{85} \mathrm{~A}$ hasty decision to commit the nation to war will probably not be compatible with democratic control, either. Speedy decisionmaking necessarily precludes the extended factfinding and debate characteristic of reasoned democracy, ${ }^{88}$ and instant

Cabinet); C. Rossiter, supra note 40, at 288-89 (1948) (democracy can better handle emergency "if the executive is empowered to take strong action without an excess of deliberation and compromise"). The need for speedy decision is greater for the country reacting to aggression than for the aggressor. W. JENNINGs, supra, at 196-97.

81. The President's unique capacity to deal with natural and economic catastrophes explains why the nation relies upon him to respond instantly to such emergencies. C. RossITER, supra note 41, at 34-35. "No man or combination of men in the United States can muster so quickly and authoritatively the troops, experts, food, money, loans, equipment, medical supplies, and moral support that may be needed in a disaster." Id. at 35. Similarly, the President's control of the military as Commander-in-Chief allows him to respond instantly to military emergencies. See W. REvelex, supra note 13, at 148-49 (historically, "need for military speed has supported executive prerogative").

82. The Supreme Court has described the President as "the Nation's organ in foreign affairs." Chicago \& S. Air Lines, Inc. v. Waterman S.S. Corp., 333 U.S. 103, 109 (1948).

83. All else being equal, the introduction of land-based combat aircraft is more likely to produce a favorable outcome than the presence of naval forces. Similarly, movements of land-based ground forces tend to be more influential than those of ship-based ground forces. B. BLECHMAN \& S. KAPLAN, supra note 77, at 101-02, 107-08, 529-30. Thus, requiring the Executive to obtain authorization from Congress before sending U.S. land-based forces to an ally threatened with imminent attack but not before stationing U.S. naval forces off an ally's coast would restrict the Executive to those types of military movements that demonstrate the least resolve.

84. See Rostow, supra note 21, at 838 (proposed Senate bill would not allow President to "make a credible threat to use force as an instrument of deterrent diplomacy"). Representative Kemp has pointed out that had legislation limiting the President's ability to take military action been in force when President Johnson, to prevent Soviet intervention in the 1967 Arab-Israeli conflict, threatened to send American troops to the Middle East, "the Soviet Union would [have] know[n] that this threat could not be enforced without action by Congress." 119 CoNG. Rec. 33,866 (1973).

85. Franck, supra note 22, at 637-38 (only Congress can "reflect the complexity, diversity, and varying degrees of intensity of American opinion" regarding desirability of warmaking).

In contrast, Clinton Rossiter has argued that the Presidency is "our one truly national political institution," since it is less likely than Congress to stray from the "national purpose" in response to pressures from "organized minorities." C. RossiTER, supra note 41, at 260 . Rossiter maintained that rather than being undemocratic, presidential power "has been more responsive to the needs and dreams of giant democracy than any other office or institution in the whole mosaic of American life." Id. at 261 .

86. Senator Fulbright has recounted how he urged passage of the Tonkin Gulf Resolution on the floor of the Senate solely on the basis of testimony given by Defense Secretary Robert McNamara at a 
consensus is likely to have arisen only from the instinct to rally around the President's position in a crisis. ${ }^{87}$ The passage of time may also be necessary to counteract the manipulation of public opinion by executive officials. .8 $^{83}$

If prior authorization of Congress were necessary to enter into hostilities, the U.S. would be physically incapable of carrying out military counter-measures in less than a few hours if Congress were in session or in less than a day or two if it were not. Moreover, even if the President obtained prior authorization in time, the congressional decision would be far less likely to have resulted from a truly democratic process than if it had been deferred to a later date. Finally, prior authorization would jeopardize military operations whose success depended on secrecy.

Thus, considerations of effectiveness and democratic control support the conclusion that when the time available for decision is extremely short or when an operation depends on secrecy, the power to introduce American forces into hostilities abroad is "executive" in nature. In these cases, one can say that the President, having been elected by the entire nation, repre-

single joint-committee meeting that lasted less than two hours. At the time of passage, Fulbright did not know that the commander of the U.S. task force in the Tonkin Gulf was uncertain as to whether the North Vietnamese had actually carried out an attack on American destroyers. Fulbright has confessed:

If I had had enough sense to require complete evaluation I never would have made the mistake

I did . . . . [O]f course I wasn't the only one. Both committees . . . accepted [McNamara's]

testimony then as the whole story, and I must say this raises very serious questions about how

you make decisions to go to war.

M. Pusey, The Way We Go To War 186-87 (1969).

87. The early popular support for the wars in Korea and Vietnam has been attributed to "a desire to support the country's leadership in time of trouble, the rally-round-the-flag phenomenon." J. Mueller, War, Presidents and Public Opinion 58 (1973). Data generated by public-opinion polls suggest that as long as Congress mirrors public sentiment, a congressional vote on the decision whether to commit U.S. forces to combat probably will be "heavily influenced" by the President's favoring the use of force, even if the vote is taken before the commitment is made. Id. Nevertheless, initial support for the President's position could erode in a matter of weeks. For example, between early February 1968, at the beginning of the Tet Offensive, and March 1968, the number of poll respondents describing themselves as "hawks" on the issue of the war in Vietnam dropped from $61 \%$ to $41 \%$. Id. at 107. Thus, in certain cases, the "rally-around-the-flag phenomenon" might exert far less influence on the legislature if the decision to commit the nation to a course of war is delayed for several weeks after the President's decision to initiate hostilities.

88. "Appearance manipulation" by the Executive has served two functions: the facilitation of military intervention abroad and the preservation of the President's overall public support. See T. Halper, Foreign Policy Crises: Appearance and Reality in Decision Making 222-24 (1971). The portrayal of the Tonkin Gulf incident as a genuine crisis, for example, enabled the President to obtain a congressional resolution permitting the escalation of the war effort. Id. at 224 . The executive branch often views the American public as simply "another audience" to be managed, as if it were a foreign government. R. BARNET, ROOTS OF WAR 266-67 (1972). The "national will" is believed to be an important component of American power; thus, the Executive sometimes seeks to "prepare public opinion" for a commitment of forces abroad by overstating a crisis. Id. at $267,271$. Other means of managing public opinion include the use of "leaks" to increase the credibility of certain perceptions of international events, and the creation of "pseudo-events" to keep public attention from focusing on actual occurrences that the Administration would like to de-emphasize. Id. at 289-91. 
sents all of the people for the purposes of crisis management. ${ }^{89}$ Similarly, the power to use force short of war in support of diplomatic efforts, as well as the power to engage in hostilities that result from such uses of force, is best characterized as "executive." More extensive commitments of force, as in the decision to go to war, are legislative functions.

Of course, Congress cannot make the final decision if the President acts in a manner that effectively binds the nation to a course of war. For this reason, the more likely it is that a military measure will bring on a national commitment, ${ }^{90}$ the greater the threat and urgency that should be present before the decision to initiate hostilities becomes "executive" in nature. ${ }^{91}$

\section{B. Presidential Discretion and the Concurrent Resolution}

On the basis of the Framers' intent, judicial precedent, and the current needs of foreign policy decisionmaking, one can conclude that the grant of "executive power" gives the President the discretion to initiate hostilities during a military emergency in the event that Congress (1) is unable to act in time or in a manner that preserves necessary secrecy; and (2) has not provided any statutory direction in advance for dealing with the crisis. In these cases, the President can act unilaterally to protect U.S. interests long enough for Congress to pass whatever emergency measures it deems necessary. ${ }^{92}$ Such independent action by the President does not constitute an assumption of the legislature's policymaking role, but is rather an attempt to ensure that Congress can make policy in circumstances as favorable as possible.

Once Congress, through a concurrent resolution, formally decides not to pass legislation authorizing involvement in certain hostilities, one of the conditions necessary for the President to initiate the use of force under the "executive power"-namely, the absence of direction from Congress-is no longer present. As a result, the President's executive power can no longer serve as a basis for the introduction of U.S. forces into combat or

89. See C. Rossiter, supra note 41 , at 260.

90. Whether a military action is likely to commit the U.S. depends primarily upon the capabilities of the state or group of states against whom the action is directed. For example, carrying out air strikes against a small nation in Asia would be unlikely to result in a national commitment: Once the U.S. decided to terminate the attacks, the other nation could no longer engage in hostilities with American forces. An attack on a Warsaw Pact nation, however, would be likely to develop into a worldwide conflict from which the U.S. would be unable to extricate itself without the acquiescence of its enemies.

91. In practice, the President must determine whether the decision to introduce U.S. forces into combat is "executive" in nature, and his determination is not amenable to judicial review. See infra note 119. However, the President can be impeached for acting inconsistently with Congress' sense of the limits of the executive power.

92. See supra p. 1343. 
for the continued conduct of military operations he has commenced. Since the President's role as Commander-in-Chief does not confer upon him any prerogative to initiate involvement in hostilities, commencing or continuing presidential warmaking ${ }^{93}$ in the face of a concurrent resolution opposing military involvement usurps the legislative function. ${ }^{94}$ Thus, when faced with a concurrent resolution opposing an executive-initiated use of force, ${ }^{88}$ the President must terminate U.S. involvement in the hostilities as soon as possible.

Commentators have argued that, in view of the Supreme Court's recent decision in Immigration $\mathcal{E}^{8}$ Naturalization Service v. Chadha ${ }^{98}$ any concurrent resolution not presented to the President for his approval would be an unconstitutional "legislative veto." ${ }^{\text {"9z }}$ In Chadha, the Court held that once Congress delegates authority to the Executive, only legislation passed by both houses and presented to the President can revoke that delegation. ${ }^{98}$ This ruling, however, does not apply to a concurrent resolution

93. But of. W. REveley, supra note 13, at 196-98 (concurrent resolution available only after President acts).

94. Technically speaking, a concurrent resolution to stop presidential war making is not legislation. In Youngstown Sheet \& Tube Co. v. Sawyer, 343 U.S. 579 (1952), although Congress did not use formal legislation to forbid the seizure of the steel mills, its decision to reject that remedy served to deny the President the authority to carry out such a measure. Id. at 599-600, 602 (Frankfurter, J., concurring). Similarly, a concurrent resolution serves to communicate a "conscious choice of policy in a field . . . within legislative responsibility for choice." Id. at 602 .

95. The principle of bicameral approval of legislation suggests that a single house of Congress can terminate a presidential initiative through a "simple resolution." Dry, The Congressional Veto and the Constitutional Separation of Powers, in THE PRESIDENCY IN THE ConstrTuTIONAL ORder 195, 211 (J. Bessette \& J. Tulis eds. 1981) (if President were to propose regulation, bicameralism would suggest "concurrent resolution of approval" or "simple resolution of disapproval"). In the context of an emergency, however, the concurrence of both Houses should be necessary. Otherwise one House might reject remedy $A$, expecting the President to carry out remedy $B$, while the other house rejects remedy $B$, expecting the President to carry out remedy $A$. The result is that the President is prevented from carrying out either remedy $A$ or $B$, an outcome desired by neither House.

96. 103 S. Ct. 2764 (1983).

97. See The Supreme Court Decision in INS v. Chadha and Its Implications for Congressional Oversight and Agency Rulemaking: Hearings Before the Subcomm. on Administrative Law and Governmental Relations of the House Comm. on the Judiciary, 98th Cong., 1st Sess. 129-30 (1983) [hereinafter cited as Chadha Hearings] (statement of Deputy Secretary of State Kenneth W. Dam) (concurrent-resolution provision "clearly unconstitutional"); Tipson, Meinorandum, 129 CoNG. REC. S12,482, S12,483 (daily ed. Sept. 20, 1983) (view of Chief Counsel of Senate Foreign Relations Committec); Lewis, Flouting the Law, N.Y. Times, Sept. 19, 1983, at A19, col. 1 (provision "effectively held unconstitutional" by Court).

The concurrent-resolution mechanism seems to violate art. I, $\S 7$, cl. 3 of the Constitution, which provides that "[e]very Order, Resolution, or Vote, to Which the Concurrence of the Senate and House of Representatives may be necessary" shall be subject to presidential veto. The purpose of this clause, however, was to make sure that a simple majority of both houses of Congress could not force the President to carry out measures with which he disagreed. 1 FARRAND Records, supra note 34, at 108 (Madison saw negative in Executive as necessary check against "the measures of . . . an unjust and interested majority"); 2 FARRAND RECORDS, supra note 34, at 301 (Madison argued that negative applied to "bills" only and "would be evaded by acts under the form and name of Resolutions, votes \&c . . . ."). The Framers did not intend the clause to enable the President to take measures expressly rejected by Congress.

98. 103 S. Ct. at 2786. 
that attempts to terminate executive-initiated warmaking, since Congress never delegated the presidential authority curtailed by such a resolution. ${ }^{90}$ Rather, the authority is based on the President's executive power to act in emergencies while Congress considers appropriate legislation. Thus, instead of circumventing the legislative process, the concurrent-resolution mechanism ensures that the President cannot wage war indefinitely without the approval of Congress simply by commencing American involvement in hostilities himself. ${ }^{100}$

A concurrent resolution, however, would not stop a President from continuing to conduct a war forced upon the nation by an enemy invasion or by an encirclement of U.S. forces abroad. The President's authority as Commander-in-Chief allows him to direct American military forces in combat as long as hostilities persist. ${ }^{101}$ In the case of invasion, the President may direct military resistance until enemy forces are no longer present in American territory or until a peace treaty is concluded. ${ }^{102}$ Likewise, he has the power, notwithstanding a concurrent resolution, to order military measures necessary to preserve and extricate military units engaged in hostilities abroad. In these situations, the President's response must be proportional to the enemy actions which prompted them; otherwise, he will have strayed from conducting war to commencing it. ${ }^{108}$

99. See Chadha Hearings, supra note 97, at 175, 186-87 (statement of Robert C. Eckhardt) (concurrent resolution was constitutional since "not employed to withdraw authority previously granted but rather to establish that power has not been given to engage in war or continue hostilities"); $c$. Carter, supra note 19, at 129-32 (resolution pursuant to $\S 5$ (c) would arguably be "extraordinary" legislation not requiring presentment to President).

100. Cf. W. Reveley, supra note 13, at 198 ("no place for executive veto" when Congress seeks to terminate "unilateral executive action").

101. This power is part of the President's power to conduct wars, however they are commenced, as first general and admiral of the army and navy. See supra p. 1337.

102. The delegates to the 1787 Convention ultimately rejected Madison's motion that less than a two-thirds vote of the Senate be required for treaties of peace. 2 FARRAND RECORDS, supra note 34, at 540-41. During the debate, Gerry warned that peace treaties pose "more danger [of] the extremities of the Continent . . . being sacrificed" than other treaties do. Id. at 541. In addition, Morris argued that Congress should make peace only with the concurrence of the President as "the general Guardian of the National interests." Id. at 540-41. If, by means of a concurrent resolution, Congress could make it illegal for the executive branch to continue the military defense of certain parts of the United States, then Congress would be able to accomplish by majority vote something that the Framers intended only the President with the support of two-thirds of the Senate to be able to bring about, namely, the voluntary sacrifice of American territory. Congress could, however, pass a statule, subject to presidential veto, that would prohibit U.S. armed forces from engaging in combat with enemy forces. Technically speaking, such legislation would not interfere with the Commander-in-Chief's power to direct military operations as he sees fit; it would simply leave him without any forces with which to carry out such operations.

103. The President's power as Commander-in-Chief to conduct a war does not include the power to commence one. See supra p. 1338. Whenever U.S. military forces are attacked abroad, a state of hostilities exists, and it follows that the President has the authority to direct the American units' defense. If, however, Congress has passed a concurrent resolution ordering the disengagement of the units involved, the President may not use the attack as a justification for embarking on a military effort disproportionate to the task of safeguarding the forces under attack. For example, if Libyan jets were to attack American warships patrolling the Mediterranean, and if Congress were to pass a 
The provisions of Articles I and II do not provide guidance for determining how long presidentially initiated war making may continue when Congress remains silent. The Constitution places no duty on Congress to consider the issue of ongoing hostilities at all, let alone within a particular period of time. Presumably, the President should discontinue the use of military force once it is evident that approval by Congress is not forthcoming, since the President could no longer justify his use of force by congressional inability to act. To continue the use of force in such a situation would be to exercise both the executive and the legislative functions. ${ }^{104}$ It follows that the duration of the President's emergency war power should reflect only the time needed for congressional fact-finding, deliberation, and debate on the issue of war and peace. But the Constitution does not tell us whether the President's discretionary power to initiate hostilities expires in two weeks or a year.

\section{Interpreting and Assessing the War Powers Resolution}

To the extent that the President's discretion to use military force without prior authorization derives from his executive power, war powers legislation is an appropriate device for adjusting the amount of discretion left to the President. Congress can also use war powers legislation as a means of communicating its sense of the constitutionally prescribed allocation of the war powers. ${ }^{105}$ In addition, such legislation may increase the likelihood that courts will reach the merits of suits brought by servicemen seeking injunctions against their being sent abroad to fight. ${ }^{108}$

concurrent resolution that called for the termination of the use of force against Libya, then the President would exceed his constitutional authority if he were to order an invasion of Libya. But the President would have the authority to direct that air cover be provided for American warships near Libya until the vessels were safely beyond the range of enemy aircraft.

104. Since the Constitution vests the legislative power in Congress, the President cannot use congressional inaction alone to justify taking measures without statutory authorization that he deems necessary. Were congressional acquiescence construed as ratification, the President presumably would be free to embark on any national programs (e.g., building dams) that interested him and to continue them as long as Congress did not take positive action to stop him. "[T]he fact that power exists in the Government does not vest it in the President. The need for new legislation does not enact it." Youngstown Sheet \& Tube Co. v. Sawyer, 343 U.S. 579, 604 (1952) (Frankfurter, J., concurring). But cf. Dames \& Moore v. Regan, 453 U.S. 654, 686 (1981) (congressional acquiescence in executive practice inferred from "character of legislation . . . enacted in the area"). Since a statute must pass both Houses of Congress, a single House has the power, in the long run, to terminate presidential war by refusing to pass the necessary authorization.

105. Sep Reveley, supra note 22, at 111 (legislation could lead to formation of "constitutional consensus" on war powers).

106. A serviceman has standing to bring a suit challenging the legality of a war "if he is under orders to fight in the combat to which he objects." Holtzman v. Schlesinger, 484 F.2d 1307, 1315 (2d Cir. 1973), cert. denied, 416 U.S. 936 (1974); accord Berk v. Laird, 429 F.2d 302, 306 (2d Cir. 1970).

An individual Congressman has standing to bring an action alleging "that conduct by officials of the executive branch amounted to an illegal nullification not only of Congress' exercise of its power, but also of [the Congressman's] exercise of his power." Kennedy .v. Sampson, 511 F.2d 430, 436 


\section{A. The Constitutionality of the Resolution}

If one accepts that the President has a broad executive power to use force and a narrow commander-in-chief power, the major provisions of the War Powers Resolution withstand constitutional attack.

If the President's power to initiate hostilities without prior authorization stems from his executive power, ${ }^{107}$ then section 2(c), which refers to his commander-in-chief powers, does not enunciate any constitutional limitations on the President's operational capabilities. Instead, it identifies those situations with regard to which Congress cannot limit the President's discretion, since any statutory limitation would infringe upon the President's authority as Commander-in-Chief. ${ }^{108}$ By implication, in all other situations in which the President introduces forces into combat, he does so on the basis of his executive power, which is subject to restrictions imposed by war powers legislation. ${ }^{108}$

A broad conception of the executive power also defends the Resolution from the charge that it unconstitutionally delegates Congress' warmaking power to the executive branch. ${ }^{110}$ If the executive power gives the President discretion to act unilaterally when he cannot expect Congress to pass the necessary laws in time, then the discretion allegedly bestowed by the Resolution has vested in the President all along. ${ }^{111}$

(D.C. Cir. 1974). The Court has refused, however, to "decide issues affecting the allocation of power between the President and Congress" until Congress confronts the President, and "the political branches reach a constitutional impasse." Goldwater v. Carter, 444 U.S. 996, 997-98 (1979) (vacated and remanded with directions to dismiss) (Powell, J., concurring in the judgment). This doctrine does not apply to private litigants, who do not have access to the resources that are available to "coequal branches of our Government ... to protect and assert [their] interests . . . ." Id. at 1004 (Rehnquist, J., concurring).

107. See supra p. 1348.

108. See supra p. 1330-31. Thus, the Resolution concedes that once Congress declares war or authorizes U.S. involvement in hostilities by statute, Congress may not prevent the President from introducing forces into combat. In addition, the Resolution acknowledges that Congress may not interfere with the President's power to react to sudden attacks on the United States or its armed forces. The statement that the President's powers "are exercised only pursuant to . . . a national emergency created by [an] attack," 50 U.S.C. $\$ 1541$ (c) (1976), reflects the notion that when the President relies solely on his authority as Commander-in-Chief, his responses must be proportionate to the enemy actions provoking them, see supra p. 1350. The degree of force that the President may use depends on the extent to which enemy action has created the emergency. The mere existence of a state of emergency during which a few nervous shots were fired at American forces would not justify the President's ordering actions inconsistent with the provisions of war powers legislation, unless the actions were necessary for the safety of the forces under fire.

109. See supra pp. 1341-42. Congress may use war powers legislation to prescribe the manner in which the President is to respond to military emergencies, just as it may establish statutory procedures for the handling of other emergencies.

110. See supra p. 1335.

111. The Resolution would have delegated power unconstitutionally if it had authorized the President to declare war or to fight a war for an unlimited period in unspecified circumstances. Congress could have authorized the President to take particular military steps in unspecified emergencies only if it retained the power to terminate the involvement in hostilities by concurrent resolution. Otherwise it would have delegated the power to commit the country to war, a power that the Constitution vests in 


\section{War Powers}

Since, on the basis of the Constitution alone, the concurrent resolution is a legitimate means of terminating uses of force carried out solely under the executive power, ${ }^{112}$ section 5 (c) does not serve to establish a concurrent-resolution mechanism, but rather to communicate Congress' sense of its constitutionality. ${ }^{113}$ Thus, one can reconcile a concurrent-resolution provision with the fact that the Resolution purports not to delegate any authority to the President. ${ }^{114}$

Given a narrow conception of the commander-in-chief power, the Resolution, by limiting the President's use of force in hostilities without statutory authorization to sixty days, does not unconstitutionally infringe upon his power to make war. The executive power allows the President to act unilaterally only when Congress has provided no statutory guidance for dealing with a crisis. When legislation expressly or by implication forbids recourse to certain actions in an emergency, the executive power must yield to the statutory provisions. ${ }^{115}$ As a result, section $5(\mathrm{~b})$, which expressly forbids recourse to the use of force for more than sixty days without specific statutory authorization, is binding on the President. ${ }^{116}$

\section{B. An Assessment}

The War Powers Resolution provides satisfactory controls on the President's power to send American forces into combat abroad. The imposition of a sixty-day limitation on presidentially initiated uses of force that do not receive congressional approval serves to ensure that Congress does not silently acquiesce in executive warmaking. If Congress finds that sixty days is not sufficient time for legislative deliberation and debate on whether to commit the nation to a particular war, it may pass an exten-

Congress. See supra pp. 1336-37.

112. See supra p. 1349.

113. See supra p. 1351; $c$. Carter, supra note 19, at 101-02, 116-17 (Resolution constitutional because it defines "war" as used in clause of Constitution granting Congress power to declare war).

114. See supra p. 1334.

115. See supra p. 1341-42. Given that Congress sometimes implicitly (but effectively) forbids the use of one remedy in an emergency simply by prescribing the use of another, it follows that it has the power expressly to forbid the President to resort to any emergency actions that are not based on his authority as Commander-in-Chief.

116. Section 5(b) provides:

Such sixty-day period shall be extended for not more than an additional thirty days if the

President determines and certifies to the Congress in writing that unavoidable military necessity respecting the safety of United States Armed Forces requires the continued use of such armed forces in the course of bringing about a prompt removal of such forces.

50 U.S.C. $\$ 1544$ (b) (1976). This provision is unconstitutional to the extent that it provides that the President may not use military force to ensure the safety of the U.S. armed forces for more than ninety days without specific statutory authorization. Indeed, the power to use force to safeguard U.S. military units flows from the President's authority as Commander-in-Chief and so Congress may not circumscribe it. See supra p. 1350. 
sion. ${ }^{112}$ The Resolution also provides "judicially discoverable and manageable standards"118 for review which would ensure justiciability in the event Congress remained silent in the face of extended presidential warmaking. ${ }^{119}$ Finally, the Resolution leaves the President with the power to respond to military emergencies and to use force short of war in conjunction with diplomatic efforts, powers that must be lodged in the Executive as long as vital national interests depend on the day-to-day projection of American military strength abroad. ${ }^{120}$

-Bennett C. Rushkoff

117. 50 U.S.C. $\$ 1544(b)(1976)$.

118. Baker v. Carr, 369 U.S. 186, 217 (1962).

119. A "lack of judicially discoverable and manageable standards for resolving" a question has been recognized as a condition that may require "dismissal for non-justiciability on the ground of a political question's presence." Id. A second such condition is "a textually demonstrable constitutional commitment of the issue to a coordinate political department." Id. These considerations, along with a general reluctance on the part of the judiciary to interfere with the conduct of American foreign policy, were responsible for numerous decisions dismissing, on the basis of the political question doctrine, suits challenging the constitutionality of U.S. military involvement in Indochina. See Sugarman, Judicial Decisions Concerning the Constitutionality of United States Military Activity in Indochina: A Bibliography of Court Decisions, 13 Colum. J. Transnat'L L. 470, 472 (1974). For an example of such a suit, see Atlee v. Laird, 347 F. Supp. 689, 702-03 (E.D. Pa. 1972), aff'd mem. Atlee v. Richardson, 411 U.S. 911 (1973).

Decisions concerning the use of military power ordinarily are not suitable matters for judicial action. See Luftig v. McNamara, 373 F.2d 664, 665 (D.C. Cir.), cert. denied, 387 U.S. 945 (1967). But once Congress has passed a concurrent resolution terminating involvement in hostilities, or has expressly forbidden in advance the use of force by the Executive for more than a specified number of days, the political department to which the Constitution commits the power of war and peace has established a clear standard for judging the legality of warmaking. Were the Executive to continue a presidentially initiated war in spite of a concurrent resolution or beyond the sixty-day period allowed by the War Powers Resolution, a federal court arguably could issue an injunction ordering the disengagement of American forces from hostilities. But see Crockett v. Reagan, 558 F. Supp. 893, 896-98 (D.D.C. 1982) (fact-finding necessary to determine whether U.S. forces introduced into hostilities or imminent hostilities in El Salvador renders suit brought by Members of Congress under War Powers Resolution non-justiciable), aff d 720 F.2d 1355 (D.C. Cir. 1983). Such an injunction would not prevent the President, acting as Commander-in-Chief, from taking whatever military actions were necessary for the safety of U.S. armed forces while he carried out the disengagement.

The President might exceed the limits of his executive power by unnecessarily entering into hostilities likely to commit the nation to war, or exceed the bounds of his commander-in-chief power by responding disproportionately to attacks on U.S. armed forces after Congress passed a resolution terminating involvement in hostilities abroad. Under the political question doctrine, the absence of "manageable standards" for review would prevent judicial action in such cases. The only remedy for the abuse of presidential power, aside from the cutting off of military appropriations by Congress, would be the impeachment of the President.

120. See supra pp. 1345-46. 